this very topic for next year's discussion, and suggested a gates are not invited, would be rather undignified on the competent committee to prepare this subject, would this part of the Section. The question of the invitation is a not come with greater force from this Associdion next different question, I am sure, if it is the feeling of the year than at the present time, if it should come after a full Section that it would be well to have the Congress mert preparation of the topic, and a full discussion in the report here the next time it meets. But 1 think we would not imof this Committee? I suggest that it be deferred for the prove the chances of our getting the Congress by extending present, inasmuch as this is a special topic for next year. a formal invitation. If the members who attend will extend

Dr. ELxis--The Secretary might be instructed to refer it to that committee.

the invitation as members of the Congress, they will be

Dr. SouthaRD--You do not assert that it means that this body of men here is not competent to claim that they believe it is well to examine children's eyes? President Jordan said to me within a few weeks that he never realized in his life the importance of this until recently, and he was very earnest in the hope that something would be done, and that I would continue to work in this line until something was accomplished. I would like to be able to go to teachers and others and say that our Ophthalmology Section does agree with me and others in the fact that it is well to have children's eyes examined. I should think we might have indorsements in that way, to assist us to carry out what we have already started upon. I believe that now is the time for commencing the work. It is simply a little indorsement $I$ want from you in my lectures throughout the State.

Dr. Coe, of Seattle-We have our teachers' associations throughout the State, and local meetings of teachers, and if this matter can be brought before the State Societies, we can get the general practitioners interested in that matter. As has been stated, Dr. Jordan even was ignorant of the dangers to be incurred through these troubles. So you find it everywhere. I have no hesitation in trying to educate the public to this view of the matter and I think if we can only adopt this resolution it will come with added force when we take it into our State Society.

The question was then put on the amendment to postpone until next year and the motion was lost.

DR. STARKEY - I have no desire to push this matter but I thought, simply as an educational measure, it might be well to have it for use during the year without postponing.

The question was then put on the original motion and carried.

The Secretary then read a letter from Dr. Savage of Nashville, suggesting that the Section extend an invitation to the International Congress of Ophthalmology to hold its next session in this country and requesting to be appointed a delegate.

Dr. TAYLOR-I do not know whether this is a matter to come before the Society or not, but $I$ suggested the reading of this letter so that it may be brought up. Probably Dr. Jackson can tell us something about this Society, so that we will know whether it would be proper for us to take action.

Dr. Jackson-I think this Congress met in New York in 1874. A Congress met there which was practically one of this series of international congresses. So far as I know, the place of meeting of the Congress has not been determined by any invitation of the Society, but by the invitation or upon the solicitation of members from a certain place, who were present at the meeting. The Congress is not a representative body at all. It does not invite delegates from other associations. Ir has a different basis of membership. There would be a good many members of the AmErican Medical Associatron who intend to be present, many of the most prominent members of the Association, but they have none of them asked to be appointed delegates to this meet. ing. While Dr. Savage may be as good a man for a delegate as anybody else, I do not see that we can appoint him simply because he suggests it. To appoint delegates where dele-

ended by this body.

The Charran-American delegates, as a rule, are received over there very coldly. It has been the custom for so many years for men of ordinary talents to secure appointment that they have grown to look upon them in rather an unfavorable light.

On motion duly seconded and carried, the following resolution was adopted and the Secretary was instructed to forward the same to Dr. Savage:

"Resolved, That inasmuch as this Section has no representative in the International Congress of Ophthalmologs, it is not deemed advisable that we appoint a representative."

The Secretary then read the minutes of this and the previous meeting.

A vote of thanks to the retiring officers was then carried and the Section adjourned.

\section{THE SWEAT-SHOPS AND SMALLPOX IN CHICAGO.}

BY BAYARI) HOLMES, M.D.

PROFESSOR OF SURGICAL PATHOLOGY AND BACTERIOLOGY IN THE COLLEGE OF PIYYSICIANS AND SURGEONS OF CHICAGO.

There is before me a document very significant to medical men. It is the first special report of the Factory Inspector of Illinois. This fifty-seven page pamphlet is a fair exposition of the condition of our western metropolis during the smallpox epidemic of the past winter and spring.

All of our readers may not know that a law was passed by the last Illinois Legislature defining the sweat-shops and denying the manufacture of clothing except by the residents in anv room used for domestic purposes. This law alsi provides that all workshops and factories shall be open to inspection, and when articles manufactured in them have been found infected with vermin or with infectious or contagious matter, they shall be reported to the local health officer to be destroyed by him. Now it appears from this report that there are about $950 \mathrm{li}$ censed shops in Chicago and 25,000 other rooms in which garments are made. The principal Factory Inspector, Florence Kelley, and her ten assistants, have had enough to do to enforce the other provisions of the law, especially in preventing the employment of children under 14 years of age in the factories; nevertheless in the fall of 1893 a few cases of smallpox appeared in Chicago. A Sister visiting the smallpox hospital on Twenty-sixth Street and Sacramento Avenue, had smallpox in Rock Island after her return, and a number of cases appeared in various parts of the State, but through the efficient efforts of the State Board of Health none of them became epidemic.

In January there was a real epidemic in the region of the Chicago smallpox hospital, and the local health officers began to show some activity. The smallpox hospital, which only needs to be mentioned to be condenned, soon became full to overflowing, and the death rate was enormous. The people began to refuse to be removed from their homes and cases 
were concealed from the authorities. At last the place became so overcrowded that no more cases could be taken at the hospital and yellow cards were tacked, usually on the back doors or hidden sides of houses, in which smallpox was found.

The duty of the Factory Inspector evidently called upon her to protect the consumers of ready-made and custom-made clothing from the danger of smallpox contagion carried by the clothing they purchased from sweat-shops in which contagion existed; therefore she informed the 176 wholesalers and merchant tailors who have their work done by sweaters, that smallpox was epidemic and that there was danger of infection, and called attention to the provision of the law for the destruction of infected goods. Only a few of the manufacturers paid any attention to the suggestions of the Inspector and various other means were taken to secure compliance with the spirit of the law.

The first goods were actually destroyed by Health Commissioner Reynolds at 699 Allport Street, on May 12. In the meantime sporadic cases of smallpox appeared almost everywhere in the Western United States. The activity of the State Boards of Health was aroused in adjoining States, and a conference was held in Chicago May 10 . The result of this conference was a contribution by the manufacturers of clothing, who employed Chicago sweaters, of several thousand dollars to be expended in the inspection of sweat-shops and in the vaccination of their workers, all to be done under the direction of the Illinois State Board of Health. In other words, the State of Illinois undertook to guarantee the non. infectious condition of the clothing manufactured in the sweat shops of Chicago for a gross contribution of $\$ 5,000$. How unsuccessfully this was done, indeed, how absurd the proposition was, and how much the country has been exposed to smallpox thereby, is shown by this report as well as by the spread of smallpox over the territory in which Chicago clothing is sold. As concrete instances are much more suggestive than any abstract dissertations I could prepare, let me copy the following cases from the Inspector's report:

May 13, 1894. John Cerenak, 645 Throop Street, coatmaker for A. A. Devore \& Sons, Michigan Avenue, corner Adams Street; Inspector Bisno.

The Inspector found in Cerenak's shop, which is one of his living rooms in this tenement house, a coat for the Devore firm in process of manufacture on Sunday, May 13. A boy lay dead of smallpox on the same premises after several days'illness. The man declined to name any other owner for the eoat than himself, and was notified by the Inspector not to remove it until it had been fumigated.

May 14. The firm of A. A. Devore \& Co., were notified from this office of the facts in Cerenak case and replied by letter that the coat belonged to them and that they would rather it should be destroyed than returned to them.

May 15. An order was served on Commissioner Arthur Reynolds, to condemn and destroy this ceat in accordance with Section 2 of the Workshop law. Dr. Henry Reynolds accompanied Inspector Bisno to the premises and demanded the coat from Cerenak, showing him the letter from Cerenak's employers, A. A. Devore \& Co, asking for its destruction. Cerenak refused to give up the coat unless paid $\$ 16$ for it and for making another one which had been returned to the firm previously. Dr. Henry Reynolds then went away, saying to Inspector Bisno that he would return for the coat the next day, bringing police to take it if necessary. Some days later he informed Inspector Bisno that he did not go back for this coat and did not know what, if anything, had been done with it. It was then too late for inspectors from this office to trace the coat, which had disappeared.

This shows where one of the most aristocratic tailors of the city has his coats made and it also shows the inefficiency of the Department of Health.

May 22, 1894. Anton Randa, 1636 West Twenty-second Street, custom tailor, for Kelley Bros., merchant tailors, 268 South State Street; Inspector Bisno.

The Inspector found Randa's shop in his living rooms in a cottage basement. There were nine people in the family, five of whom, Randa's wife and four of his children, were sick with the smallpox. The four small rooms are used for eating, sleeping, living and manufacturing, and in the room used for a shop are two machines, three chairs, two tables and one bed. No goods were found in the shop, nor was Randa there, but as the Inspector was informed by Randa's child, he had gone after more work. The five smallpox patients were at this time in the house.

At 8 P.M. the Inspector returned to Randa's house, found him and learned that the patients had been removed to the pest house. Randa at first insisted that he had not had any work for six months, but finally admitted that he had worked for Kelley Bros., 268 South State Street; that he had delivered to them a coat very recently and that he had also taken from them one coat to make on this day, May 22. Where this coat was he absolutely refused to tell, nor could Inspector Bisno find it on the premises.

May 23. Inspector Stevens went to the store of Kelley Bros.; neither of the partners were there; this case was reported, as above, to their cutter, and an order on Randa for the coat in his possession was obtained. This cutter also told Inspector Stevens that the other coat had been returned by Randa on Thursday, May 17, and had been delivered to a customer. 'The Inspector asked for the name and address of this customer, which the cutter claimed not to know. An order was issued for Commissioner Reynolds to destroy, in accordance with Section 2 of the Work-shop law, any goods in process of manufacture found in Anton Randa's possession. Inspector Bisno, accompanied by two agents of the Board of Health, returned to 1636 West Twenty-Second Street and gave Randa the order from Kelley Bros. for the coat. Randa then cook them to 1616 West Twentysecond Street, on which premises he had concealed the work, and produced it. They found a boy in the family where this coat was concealed who appeared to have smallpox, and the Inspector remained there until a district physician was obtained, who diagnosed the case as smallpox.

The infected coat was then taken to an adjacent vacant lot and burned by the agents of the Joard of Health in the presence of Inspector Bisno.

The district physician having given his opinion that the coat returned by Randa to Kelley Bros. on Thursday, May 17 , was undoubtedly in an infected condition, Inspectors Stevens and Bisno went to the store of Kelley Bros. to make another attempt to trace the coat. This time one of the partners was in the store; he was told of the destruction of the coat found hidden at 1616 West TwentySecond Street and of the circumstances under which the coat, returned to him on May 17, was made. Inspector Stevens then told Mr. Kelley that the district physician had decided that this coat was also infected and again asked for the name and address of the customer who had received it. Mr. Kelley replied that the coat was still in the store and that he was willing that it should be destroyed. When told that his cutter had that morning reported the coat was delivered to a customer, Mr. Kelley replied that this was not so; that the coat was still in the store.

May 24. An order was issued for Commissioner Reynolds to destroy this coat in accordance with Section 2 of the Work-shop law. Inspector Bisno went with the two agents of the Board of Health to Kelley Bros'. store, where they were given a coat which the city agents burned in the presence of Inspector Bisno.

Can the dangers of tenement house manufacture be more drastically manifested? Randa concealed from the merchant tailors who gave him the coats, the fact that smallpox was in his family, although even while he returned work to them and received 
more from them, five victims of the disease lay in the tenement rooms where the work was done. Again he concealed the work from the State Inspectors, and in so doing exposed it still further by hiding it in another house where also there was smallpox.

April 30, 1894. J. Kolka, $625 \mathrm{~W}$. Twenty-first Street a coatmaker for Pfaelzer, Sutton \& Co., Franklin and Van Buren Streets; Inspectors Stevens and Bisno.

This shop is in the rear of Kolka's living rooms on the first floor; the entrance is by a side door used also in going to the living rooms. The Inspectors found Kolka and his wife, with two men visitors in the shop, and sixteen coats for Pfaelzer, Sutton \& Co., in process of manufacture. The living rooms of the Kolka family were closed and in process of fumigation. A 10 year old son of Kolka died of smallpox on Saturday, April 29. The fumigator from the Board of Health had left the premises before the State Inspectors reached it, but he had not fumigated the shop nor disinfected the coats, telling the Kolkas that it was not necessary, although the parents of the child had attended their patient and worked on the coats at the same time. The Inspectors asked Kolka when he returned the last work to the firm employing him. Kolka does not talk English easily and Mrs. Kolka, who attends to that part of the business, positively asserted that it was several weeks since they had any work except the sixteen coats then on the premises and that none had been returned since the boy was taken sick.

Inspector Stevens reported to Pfaelzer, Sutton \& Co., the infectious condition of the sixteen coats on Kolka's premises. and received their promises not to accept the goods until said goods had been properly disinfected. The Inspector repeated to them Mrs. Kolka's assurance that no goods had been returned to them since April 13 and requested them to ascertain from their books if this was correct. The books showed that Mrs. Kolka had returned to them sixty-one coats on April 23, while smallpox was in the house. They were enabled to identify the coats by their ticket system, and as these coats were in a separate lot they requested that these aiso might be disinfected and agreed to keep them boxed away from other goods until this was done.

Inspector Stevens went from Pfaelzer, Sutton \& Co.'s store to the Board of Health and finding Commissioner Reynolds absent, reported this case in detail to Secretary McCarthy of the Board, receiving his assurance that both lots of goods should be disinfected the next morning.

May 5, Mr. Meyer, from Pfaelzer, Sutton \& Co., after waiting five days for the City Board, reported to this office that no one from the Board of Health had yet visited their place; that the sixty-one coats were not yet disinfected; that the sixteen coats had been returned from Kolka without the knowledge of the firm, and that they feared these also were not disinfected. At his request, Mr. Meyer accompanied Inspector Stevens to Commissioner Reynolds office to inquire why the disinfection had not been done as promised by Secretary McCarthy. Neither Commissioner Reynolds nor his Secretary had any excuse to offer. They did not know why no fumigator had been to the business place of Pfaelzer, Sutton \& Co., and had no records to consult to show whether the shop and coats at 625 West Twenty-first Street had been fumigated. The Inspector finally succeeded in getting a reluctant promise from Secretary McCarth that the two lots of coats at Pfaelzer, Sutton \& Co.'s should be fumigated that (Saturday) afternoon or Monday morning. In the presence of the Inspector, Secretary McCarthy tried to dissuade Mr. Meyer from having this done, because of the trouble involved.

May 7. Inspector Stevens visited Pfaelzer, Sutton \& Co. in the afternoon and found that the city fumigator had not yet been there; then visited Secretary McCarthy and gave him until 9 o'clock the next morning to fulfill his promise.

May 8. At 10 o'clock a message was received at this office from Pfaelzer, Sutton \& Co. that the fumigator was there.

The utter inadequacy of the measures taken to prevent the spread of infection by these seventy-seven coats is apparent. The Kolka boy was sick a week before a doctor was called, when the child was dying. Before the report of the diagnosis reached the City Board of Health, or this office, the child was dead and buried. It was nine days after this before the City Board of Health fumigated the coats and fumi gation, under these circumstances, can by no means be considered a guarantee of disinfection. These goods should have been burned, but the Commissioner of Health refused to comply with the Section of the Work-shop act, which enjoins the Board of Health to condemn and destroy goods under such circumstances.

May 14, 1894. John Smethoma, 1189 Albany Avenue, contractor for A. L. Singer \& Co., 168-170 Market Street; Inspector Kelley.

Dr. Brand telephoned that he had found bundles of goods for manufacture on the premises of John Smethoma which he believed to be infectious for the following reasons: An undertaker, now living at 1117 Albany Avenue, had occupied the premises at 1189 Albany Avenue. One of his children had the smallpox there and recovered without the fact becoming known to the Board of Health; then another son was taken ill and the family was removed to 1117 Albany Avenue, where the second child died of smallpox. After the undertaker moved out of 1189, John Smethoma moved in, occupying the same flat which had not been fumigated and using for a shop a room to which the undertaker's family had free access throughout their illness. Dr. Brand had notified Smethoma to hold the goods until further notice.

May 15. Inspectors Kelley and Bisno, went to 1189 Albany Avenue and found the shop empty and Smethoma sitting in the street in front; he denied that he had had any work within four months and said that before Christmas he worked for A. L. Singer \& Co. At this office his name was found upon the list of Singer's employes. The firm was then notified as follows:

Messrs. A. L. Singer \& Co., 168-1\%0 Market Street, Chicago.

Gentlemen:--There is smallpox at 1189 Albany Avenue where one, Smethoma, is working for your house. There has been infection on these premises since April 1, at least; one death and a series of smallpox cases. Day before yesterday, goods in process of manufacture were found in the shop and the man was ordered not to remove them until they had been disinfected; this morning we find that the goods are gone; they must have been returned to you or left in some other place, perhaps secreted in another equally infected place. Kindly let us know by bearer if these goods have been returned to you and if you have any other goods made up by this man in your stock. To prevent the spread of infection the goods the man has disposed of, must be found and taken care of in the proper manner. Yours very truly

Florence KeLLey.

The following reply to this letter was brought back by Inspector Hickey :

A. P. Stevens, Assistant Factory Inspector:-We have not received any work from Smethoma, 1189 Albany Avenue, since April 26. We will find out if expressman delivered any work this week.

Respectfully yours,

A. L. Singer \& Co.

Later the following was received from this firm on the same date, May 15 :

A. P. Stevens, Assistant Factory Inspector :-Since your man called here this afternoon, we have found that the expressman delivered to Smethoma, 1189 Albany Avenue, twentythree men's coats and twenty-seven children's coats on the 11 th inst.

Respectfully yours,

A. L. Singer \& Co.

May 16. Mr. A.L. Singer brought Smethoma to this office to state where the Singer goods were secreted; at this time Smethoma's own child lay dead of smallpox at 1189 Albany Avenue the death occurring this morning. Inspector Hickey went with Smethoma to see where the goods were hidden and reported that they were in barrels packed in a loft of a barn or shed on premises at 1189 Albany A venue, with empty barrels piled on top of those in which the goods were hidden. Inspector Hickey reported also that on the way to locate the goods the man Smethoma entered two drug stores looking for a doctor to make arrangements for the burial of his child although, as he informed Inspector Hickey, he had not had his clothes off nor had he washed for three days during which he had attended the child now dead.

At 3 o'clock on this day (May 16) the Singer goods in Smethoma's possession were burned by an Agent of the Board of Health, in Inspector Hickey's presence, and with a mob of Smethoma's neighbors surging about the place 
On this day the records of the Board of Health show that there were three new cases of smaljpox at 1189 Albany Avenue. To this date there had been at no time any effort to quarantine the place

May 29. Smethoma came to this office to get permission to resume work and produced the following certificate:

May 28,1894 .

To whom it may concem :-This is to certify that the store 1189 Albany Avenue has been fumigated on May 17, and no more smallpox exists about the place. He can be allowed to resume business. W. E. MILLER, M.D.

Medical Inspector Health Department.

The Health Department records show three cases of smallpox at this number May 17 , and one new case on May 22 , again in the family of Smethoma the tailor. Including the two cases in the undertaker's family, which were not made a part of the Health Department's records, there were seven cases of smalipox, at least two fatal, on these premises in May, yet this shop certificate was issued by a city district physician, that work could be resumed there during that month. It can hardly be needful to state that this permis sion to resume work was not indorsed by this office.

The history of this shop is the history of the fatal concealments incident to tenement house manufacture. The undertaker concealed from the Board of Health the fact that smallpox was in his family. The incoming tenant, Smethoma, was therefore not warned that there had been smallpox there in the family of the out-going tenant, the undertaker. Smethoma in turn concealed from A. L. Singer \& Co., for whom he worked, the fact that there was smallpox in his family on May 16, and concealed their work on his premises from the State Factory Inspectors.

When it is considered that there has been throughout the epidemic in the Bohemian sweat-shop district, concealed cases of smallpox, so many that the district physician in charge once stated to an inspector, his belief that there were at that moment not less than five hundred cases within a radius of six blocks, the painful conviction forces itself upon us that the Smethoma case is typical of many which, with all our efforts. we failed to reach.

The inspection of the sweat-shops has been entirely ineffectual so far as concerns securing safety to the consumers of Chicago made goods. The appearance of smallpox in the better part of the city has not, so far as the writer knows, been traced to coats or other clothes made to order, but it seems incredible that such a source could not have been traced from some of the very many, otherwise unaccountable, cases which occurred last winter in respectable families.

There are many reasons why the public was not informed on this subject at the time; the principal one lies in the utter servility of the press to trade. There was at all times, during the epidemic the greatest difficulty in getting the columns of of the daily papers open to smallpox news. The conspiracy of silence was almost impregnable. In this conspiracy it seems very strange that the Commissioners of Health should have been involved but Inspector Kelley says, Section 41 :

After June 10, the Board of Health adopted an avowed policy of concealment. From this time the lists of new cases, which had before been imperfect from a lack of system and of responsible book-keeping, were rendered absolutely worthless by order of the Commissioner of Health. District physicians were notified to give out no more information and the city hall lists were reduced to two cases per day. One example of suppression of cases may serve to show how far this policy has been carried. Since it was inaugurated three children of the McLaughlin family, living in a tenement house at 82 Brown Street, were removed to the pesthouse on three different days. None of the three cases appear on any list. One omission may be explained away as accidental, but not three in the same family, the same house, the same month.

Throughout the epidemic there has been no mortality record by days or weeks from which we might have formed at least an estimate of the varying degree of danger. Admissions and discharges at the pest-house are known only to the Sister in charge of them, and the daily number has at no time been obtainable from the Health Department.
The yellow card which would be of inestimable use to us if posted, and kept in place upon infectious premises, as pre scribed by the city ordinance, has been tacked upon rear sheds and in hall-ways, upon inside doors, up three flights of stairs and in many cases has never been posted at all. Cards have been torn down in scores of cases but not one prosecution has been instituted by the Board of Health for this serious offence against the public safety. Trade has been carried on in groceries, milk depots, cigar shops and drug stores, while the warning card was either gone altogether or carefully concealed in an upper story or a rear yard and customers, ignorant of their danger, visited the infected premises as usual. From this connivance of the local officials at the infamy of landlords and shop-keepers, the State inspectors have suffered with the rest of the community, finding cases too late to take any effective measures for the enforcement of the law, and of ten failing altogether to learn of the presence of smallpox until weeks after the burial of the patient. And this in spite of faithful daily searching in the infectious district.

The guarding against recurrence of the disease on the same premises with garment making, has been further hindered by the removal of the yellow card immediately after fumigation. Where a patient was removed in the morning and the premises were fumigated and the card removed in the afternoon, an Inspector calling an hour later would find no hint of danger and a sweater might go on with his work the next day undisturbed!

Throughout this whole epidemic the value of trade and the worthlessness of human life and health, in the estimation of those in authority, has been abundantly manifested. The pest-house would disgrace Siberia by its management; it was over-croweded beyond a military prison in war time; it received no proper medical supervision and aroused no effort to improve its condition.

In the State of Illinois, one hundred of the wealthy manufacturers have clubbed together to fight the constitutionality of this factory law. The brief which their well paid attorneys prepared for the $\mathrm{Su}$ perior Court is before me. In it, property right and personal right over property, is the principal theme.

This review is written to arouse in medical men an interest in the protection of the consumers of sweat-shop made goods of all kinds; to show the utter wickedness and folly of allowing such manufacture at all; to stimulate an interest in factory legislation and to draw attention to the need of act ual coördination of the various functions of the State for the protection of our coming generation and our own peace of mind. Unless we, the most altruistic of all the educated classes, the most in touch with the people, the best prepared to judge, inter est ourselves in these maladies of the State, how can we expect any attention to them from the courts, the legislature or the clergy?

\section{CAUTERIZATION OF THE NARES, AND ACCI- DENTS THAT MAY FOLLOW}

Read before the Annual Meeting of the Illinois State Medical Society, Decatur, May 15-17, 1894 .

BY E. FLETCHER INGALS, A.M., M.D. CHICAGO.

Although from time to time articles bave been written to show that serious accidents, often follow cauterization of the nares, I think that, when properly done, this operation is quite as free from discomfort or danger as any other minor surgical procedure.

I have occasionally heard of serious results following these operations, but have never had one in my own practice, and I believe that as a rule they are due to carelessness or inexperience upon the 